\title{
Influence of Supply Chain Management on Performance of Textile Firms in Kenya, A Case of Nairobi City County
}

\author{
Dr. Noor Ismail Shale John Kiari Osoro \\ Jomo Kenyatta University of Agriculture and Technology, School of Human Resource and Development \\ PO Box 62000-00200, Nairobi, Kenya
}

\begin{abstract}
This study intended to establish the influence of Supply chain management on performance of textile firms in Nairobi City County.. This study used descriptive research design. Both qualitative and quantitative research design was used to complement each other. The target population of this study was 120 respondents from the textile firms in Nairobi City County. This is the unit of analyzes. My unit of observation was the seven textile firms. For this study the unit of analysis comprised: two senior textile managers, two senior procurement officers and one senior officer from finance in each of the firms. The study opted to do a census survey since the firms were very few. A purposive random sampling technique was used to pick the right respondents. Pilot test of 10 $\%$ was done for the purpose of confirming reliability and validity of the research instruments:
\end{abstract}

Keywords: Claims, Delivery, Administration

DOI: $10.7176 /$ IEL/9-2-02

Publication date:March $31^{\text {st }} 2019$

\subsection{Introduction}

In supply chain management production planning is the process of determining a tentative plan for how much production will occur in the next several time periods, during an interval of time called the planning horizon. Production planning also determines expected inventory levels, as well as the workforce and other resources necessary to implement the production plans. Production planning is done using an aggregate view of the production facility, the demand for products and even of time (ex. using monthly time periods). Production planning is commonly defined as the cross-functional process of devising an aggregate production plan for groups of products over a month or quarter, based on management targets for production, sales and inventory levels (Lysons \& Farrington, 2013).

According to Jeffreys and Thomas (2010), this plan should meet operating requirements for fulfilling basic business profitability and market goals and provide the overall desired framework in developing the master production schedule and in evaluating capacity and resource requirements. In supply chain management production scheduling defines which products should be produced and which products should be consumed in each time instant over a given small time horizon; hence, it defines which run-mode to use and when to perform changeovers in order to meet the market needs and satisfy the demand

In Nairobi city county textile firms have gained huge recognition due to its potential in play a key role in employment and increasing economic diversification for Kenyan citizens hence in the long run offering new opportunities for Kenyan businesses to get an increasing share of the global market. The textile sector played a substantial role in underpinning the African Growth and opportunity act. It also shows there is offers more opportunities for growth and job employments to the young citizens through the increased value capture and logistics systems that are streamlined (Toroitich, Mburugu \& Waweru, 2017). The textile sector in Kenya grew at $3.5 \%$ in 2015 and $3.2 \%$ in 2014, contributing $10.3 \%$ to gross domestic product (GDP). On average, however, textile has been growing at a slower rate than the economy, which expanded by $5.6 \%$ in 2015 . This implies that the share of textile in GDP has been reducing over time. As a result, it can be argued that Kenya is going through premature deindustrialization in a context where textile and industry are still relatively under-developed. Kenya seems to have 'peaked' at a point much lower than in much of Asia (Chandra, 2010).

\subsection{Inventory Management}

Inventory is the total amount of commodities or materials contained in a store house or warehouse at a given time. It can refer to both the total amount of commodities and the act of counting them (Subba, 2016). Inventory management refers to the tracking and management of commodities which includes the monitoring of commodities moved into and out of stockroom locations and the reconciling of the inventory balances. Inventory management plays a crucial role in providing efficient flow of materials from upstream side of the supply chain to the downstream. In the long run this ensures the required goods and services for the textile firm are readily available to the market at an affordable prices. In the firm, all inventory policies must be of benefit by driving period operating expenses and working capital requirements (Solomon \& Ayebale, 2017).

According to Simiyu (2016), inventory management involves all activities put in place to ensure that the customer has the needed product or service. Inventory management coordinates the manufacturing, procuring 
and distribution functions in order to try and much the gap between supply and demand also to ensure that the production process is continuous. Procurement management is required at different aspects and point of supply chain considering that a ware house is among the basic element to a supply chain. The scope of inventory management also involves managing the replenishment of goods, lead time, return and defect goods and demand forecasting, carrying costs of inventory, asset management, physical space, demand forecasting, cost reduction, inventory valuation. Inventory visibility, future inventory price forecasting and quality management. With a well-controlled system that can balance all the listed requirements above and with the aid of some few techniques i.e. Economic Order Quantity (EOQ). It is quite possible to have inventory levels that are optimal. Hence considering that business need and consumer needs are not always constant this agitates the need to have a continuous review and improvement process in quality (Shiferaw, 2015).

\subsection{Relationship Management}

This is an approach used by many organizations in aid to improve and strengthen their relationship with the suppliers in order to improve the customer satisfaction in the long run. It also helps in engaging the suppliers in a specific level that will improve the organizations performance. In this case this mean that in any perfect competition market where by the similarities among product are heterogeneous and difficult to differentiate their cannot be a single strategy that can be applicable to all suppliers due to different costs involved by every supplier in producing a single unit (Pervan, Pervan \& Curak, 2017) In the textile market the is always high level of competition hence more emphasis and focus is shifted to very small elements that impact the returns of the organization. In order for relationship management to work collective unit in improving the performance of the textile firm in relation to the supply chain management improvement all employees and stakeholder in the firm must understand the majority of the benefits accrued by ensuring the organization has health long term relation with their suppliers at all times. This will ensure that all workers in the firm work towards ensuring the procurement goals and organizational resources are collectively utilized in yielding value for money for the customer hence contributing more to the firms demand function (Owuoth \& Mwangangi, 2015).

\subsection{Information Flow}

Managing information flow (MIF) can often give firms a competitive advantage by providing the right information to the right people in the right format and at the correct time. In many cases, firms and individuals are willing to pay firms for this type of information. The primary purpose of an MIS is to help an organization achieve its goals by providing managers with insight into the regular operations of the organization so that they can control, organize, and plan more effectively and efficiently (Osei-Tutu, 2016). One important role of the MIS is to provide the right information to the right person in the right fashion at the right time. In short, an MIS provides managers with information, typically in reports, that support effective decision making and provides feedback on daily operations. Note that business transactions can enter the organization through traditional methods or via the Internet or an extranet connecting customers and suppliers to the firm's transaction processing systems ((Pervan et al., 2017).

According to Omisore (2014), the use of management information systems spans all levels of management. That is, they provide support to and are used by employees throughout the organization. Data that enters an MIS originates from both internal and external sources. The most significant internal source of data for an MIS is the organization's various TPSs and ERP systems and related databases. One of the major activities of a TPS is to capture and store the data resulting from ongoing business transactions. With every business transaction, various TPS applications make changes to and update the organization's databases. For example, the billing application helps keep the accounts receivable database up to date so that managers know who owes the company money. These updated databases are a primary internal source of data for the management information system. In firms that have implemented an ERP system, the collection of databases associated with this system is an important source of internal data for the MIS. Other internal data comes from specific functional areas throughout the firm (Oluoch, 2015).

\subsection{Lead Time}

According to Normanyo, Ansah and Asante (2016) It is obvious to take note that these days especially in the textile sectors demand and supply will never be the same at all time but one of the main priorities in majority of the organizations is to come up with mechanisms to reduce the taken in distribution and supply of the products demanded at the market. This also requires a continuous update and follow up of the cycle of demand by forecasting the quantities which might be ordered in the next purchase. Due to increased competitive levels and changes in the market it almost uncertain that any firm can know for sure their demand level. Regardless of the time take from point of order to need satisfaction proper understanding of the competitive nature from other suppliers and distributors in order to stay proactive and remain competitive win not only the local market but also the global market. 
According to Lysons and Farrington (2013) When firm compete the main focus should be to ensure that they remain at the market and retain their market share especially in the textile industry whereby their products are heterogeneous this will ensure that the cost of production is reduced, minimum waste and increasing returns. Proper management of time is one of the important element in giving the customers value for their money. Consider a scenario whereby the raw materials intended to be used are perishable this call for the essence of the supply chain managers to increase efficiency in their activities both in and outside the supply chain. According to Normanyo et al.(2016), noted that an illustrated that any supply chain function that is effective must ensure that its operations and activities either inbound or outbound are structured in a way that the lowest capacity of resources used as raw materials generates the highest possible amount of production. Lead time in many instances is also referred to the time element on how quick the supply chain function can adequately respond to the realized opportunities and threats with minimal negative effect on the two organizations returns both in the long and short term interval during the production cycle. When textile firm takes into account this two element of flexibility and efficiency this will enable the organization to always quickly respond to deliverable $\mathrm{s}$ and needs from their customers with minimal time possible. This two element will not only improve customer satisfaction but also improve operations and activities effectiveness (Njogu \& Gichinga, 2016).

\subsection{Performance of Textile Firms}

Performance is the competency of an organization to transform the resources within the firm in an efficient and effective manner to achieve organizational goals (Barasa, Simiyu, \& Iravo, 2015). Organizational goals vary depending on the purpose for which they are established. Business organizations, like textile firms, have profit, growth and survival as the main goals. The popular ratios that measure corporate performance can be summarized as profitability and growth: return on assets (ROA), return on investment (ROI), return on equity (ROE), and return on sale (ROS), revenue growth, market shares, stock price, sales growth, liquidity and operational efficiency. According to Chandra (2010), proposed two measures of return on assets and sales growth for measuring firm performance: objective (actual amount) and subjective (perception). If objective performance measures are available, they should be utilized otherwise, subjective performance measures will be the alternative due to the absence of accurate objective performance measures.

The competition keeps on increasing in today's and the only firms that remain at the global markets are those with strong supply value chain with a back bone of a reliable competitive advantage. In any case supply chain as a benefit to many firms seeking to flourish in this dynamic world by helping the firms in solving and managing risks also complexities in the global sourcing market. Integration and team work is so crucial for the success of an effective and efficient supply chain activities from upstream to downstream. Also the participants of the supply chain function must focus on achieving the same goals and objectives, the supply chain function is characterized by long health relationship with the suppliers, the flow of materials from the right source, at the right or rather best price, at the right quantity, right quality and distributed to the right location at the required time (Ogot, 2014).

1.1 Table Reliability Coefficients test

\begin{tabular}{lc}
\hline Variable & Cronbach's Alpha \\
\hline Inventory management & 0.891 \\
Supplier Relationship & 0.788 \\
Information Flow & 0.833 \\
Lead Time & 0.793 \\
Performance of Textile firms & 0.871 \\
\hline
\end{tabular}

The research design in this study was descriptive research design. The study describes the phenomena of this study in details with the help of both qualitative and quantitative research design. This approach allows both the qualitative and qualitative approaches to complement each other in addressing the research problem the study is trying to solve (Cheng, Fung Kei,2014).. The design was very helpful considering the level of competition which increases every minute it is imperative to ignore the times of events that have a cause-effect on the perforce of textile industry and this approach puts more emphasis on matters at hand rather than the past and the future which is uncertain. Finally it provides facts and suggestions on relationship between variables and their apparent causes (Franzosi, Roberto; Doyle, Sophie; MeClelland, Laura; Putnam, Caddie \& Civari, Stefanie, 2013). 
Table 4.16 Relationship Management on Performance

\begin{tabular}{lll}
\hline Project Management & Mean & Std. Dev \\
\hline Adequate planning avoids the stalling of Supply Chain practices & 3.674 & 1.1718 \\
A good procurement plan ensures reliable selection & 3.768 & 1.3317 \\
Monitoring ensures Supply Chain practices are delivered within & 3.896 & 1.4001 \\
probability of local firm growth & 3.506 & 0.9912 \\
Performance of Textile firms & 3.549 & 0.8615 \\
\hline
\end{tabular}

\subsection{Model Goodness of Fit}

Regression analysis was used to establish the strengths of relationship between performance of textile firms for (dependent variable) and the predicting variables; Inventory Management, Relationship Management, information flow and lead time (independent variables). The results showed a correlation value (R) of 0.761 which depicts that there is a good linear dependence between the independent and dependent variables. This is tandem with the findings of Githui (2012).

Table 4.21 Model Goodness of Fit

\begin{tabular}{llll}
\hline $\mathbf{R}$ & $\mathbf{R}^{\mathbf{2}}$ & Adjusted $\mathbf{R}^{\mathbf{2}}$ & Std. Error of the Estimate \\
\hline 0.851 & 0.761 & 0.798 & 0.057 \\
\hline Predipt
\end{tabular}

a. Predictors: (Constants), Inventory Management, Relationship Management, information flow and lead time $b$. Dependent Variable: performance of textile firms

With an adjusted R-squared of 0.761 , the model shows that inventory management, relationship management, information flow and lead time explain $76.1 \%$ of the variations on performance of textile firms while $23.9 \%$ is explained by other indicators which are not inclusive in study or model. A measure of goodness of fit synopses the discrepancy between observed values and the values anticipated under the model in question. This finding is in line with the findings of Mbaka (2017).

\subsection{Analysis of Variance (ANOVA)}

From the results in table 4.22, analysis of variance statistics was conducted to determine the differences in the means of the dependent and independent variables to show whether a relationship exists between the two. The Pvalue of 0.05 implies that performance of textile firms has a significant relationship with Inventory Management, Inventory Management, Relationship Management and information flow which is significant at $5 \%$ level of significance.

This is in line with the findings of Kamau (2013), who observed that this also depicted the significance of the regression analysis done at $95 \%$ confidence level. This implies that the regression model is significant and can thus be used to evaluate the association between the dependent and independent variables. This is in line with the findings of Mogere,et al. (2013) who observed that analysis of variance statistics examines the differences between group means and their associated procedures.

Table 4.2ANOVA TEST

\begin{tabular}{llllll}
\hline & Sum of Squares & df & Mean Square & F & Sig. \\
\hline Regression & 4.143 & 1 & 1.046 & .451 & .003 \\
Residual & 6.432 & 85 & .485 & & \\
Total & $\mathbf{1 0 . 5 7}$ & $\mathbf{8 6}$ & & & \\
\hline
\end{tabular}

\subsection{Regression Coefficients of Determination}

To determine the relationship between the independent variables and the dependent variable and the respective strengths, the regression analysis produced coefficients of determination. Findings in table 4.23 above reveal a positive relationship between motivation of employees for job satisfaction and all the independent variables. The following was produced using the multiple regression model

$Y=\alpha+\beta_{1} X_{1}+\beta_{2} X_{2}+\beta_{3} X_{3}+\beta_{4} X_{4}+\varepsilon ;$ where,

$\mathrm{Y}=$ Performance of Textile firms;

$\alpha=$ Constant; $\beta_{1}-\beta_{4}=$ Beta coefficients; $X 1=$ Inventory Management $X_{2}=$ Relationship Management; $X_{3}=$ information flow; $\mathrm{X}_{4}=$ Lead time and $\varepsilon=$ Error term, from the result shown below, it's clear that when all the independent variables are regressed against the dependent variable the constant gives a negative result meaning there is a strong relationship and how each predictor has an effect on the dependent variable. 
Table 4.23 Regression Coefficient Results

\begin{tabular}{|c|c|c|c|c|c|}
\hline & \multicolumn{2}{|c|}{ Unstandardized Coefficients } & \multirow{2}{*}{$\begin{array}{l}\text { Standardized Coefficients } \\
\text { Beta }\end{array}$} & \multirow[t]{2}{*}{$\mathbf{t}$} & \multirow[t]{2}{*}{ Sig. } \\
\hline & B & Std. Error & & & \\
\hline (Constant) & -.183 & .060 & & -1.143 & .023 \\
\hline Inventory Management & .423 & .112 & .838 & 5.471 & .000 \\
\hline Relationship Management. & .249 & .068 & .162 & 2.471 & .041 \\
\hline Information Flow. & .374 & .059 & .587 & 4.386 & .000 \\
\hline Lead Time & .647 & .115 & .321 & 2.654 & .017 \\
\hline
\end{tabular}

a. Predictors: (Constants), Inventory Management, Relationship Management, information flow and lead time

b. Dependent Variable: performance of textile firms

A unit change in Lead time would thus lead to a 0.647 effect on performance of textile firms for ceteris paribus; while a unit change in Lead time would have an effect of 647 change in on performance of textile firms, a unit change in inventory management would have an effect of .423 change in on performance of textile firms also a unit change in Relationship Management would have an effect of .249 change in on performance of textile firms and finally a unit change in information flow would have an effect of .374, change on performance of textile firms. This finding is in line with the findings of Mbaka (2017). This implies that among other factors, Inventory Management, Relationship Management, information flow and Lead Time are significant determinants of performance of textile firms.

\section{Summary of the Findings}

The main finding of the study and which tended to answer the research aim was that inventory management, relationship management, information flow and lead time are factors that have direct effects of textile firms, and accounts for up to $76.1 \%$ of the variation on performance of textile firms. The summary of specific findings is presented in line with the four objectives that informed the study.

\section{Recommendations}

Involvement of inventory management is paramount and has direct impacts on performance of textile firms. The inventory management so adopted fails to foster best practices of modern firms and inclusiveness participation resulting in poor performance of the textile firms. Relationship management is fundamental to the understanding of poor performance of the textile firms and has direct impacts on performance of textile firms in Kenya. Such facilitation is an element to foster growth in textile firms' such as textile firms seem to have been ignored, and this may lead to their bad performance. The use of information flow has positive impact on performance of the textile firms in Kenya. How integration of the information flow works which would see the application of systems such as Enterprise Resource Planning is still in its nascent stages and does not, therefore, support improved performance of the textile firms. Lead time help in streamlining procurement processes in the firms by, for instance, setting out the Re-order Levels for the purpose of expediting the orders when need arises and the application of Just in Time as the best practices. Modernized firms have adopted the best practice of JIT and ERP systems. Textile firms have remained lazed on such policies, which essentially results in poor performance.

\section{REFERENCE}

African Cotton \& Textile Industries Federation (ACTIF) (2013).Policy Research on the Kenyan Textile Industry. Nairobi: ACTIF.

Amemba, C.S., Nyaboke, P.G., Osoro, A., \& Mburu, N. (2013). Challenges affecting public procurement performance process in Kenya.International Journal of Research in 'Management, 3(4), 41-55

Barasa, P. W., Simiyu, G. N., \& Iravo, M. A. (2015, June). impact of supply chain collaboration practice on the performance of Steel Manufacturing Companies in Kenya. European Journal of Logistics Purchasing and Supply Chain Management, Vol.3 (No.2), 28-39.

Bernama M 2013 M. Zhang \& B. Huo, "The impact of dependence and trust on supply chain integration," International Journal of Physical Distribution \& Logistics Management, 43, 544-563

Billy Gray, Erick C., Jones, Yvette Weatherton, RestuSunarto-Bussey, Harrison Armstrong (2013). Utilizing Pipeline Quality and Facility Sustainability to Optimize Crude Oil Chains"The International Journal of Supply Chain Management Vol.2.

Brown, B., \& Hyer, N. (2010). Managing Supply Chain practices: A Team-Based Approach. (International ed.). Singapore: McGraw-Hill.

Burnette, M., Stank, T., \& Dittmann, P. (2014). Global supply chains. Faculity at the University of Tennessee McGraw-Hill Professional.

Byrne, B. M. (2010). Structural Equation Modeling with AMOS: Basic Concepts, Applications, and Programming. New York, NY: Routledge. 
Chandra, P. (2010). Project Planning, Analysis, Selection, Financing, Implementation and Review (7th Ed.). New Delhi: Tata McGrawHill Education.

Cheng, Fung Kei (2014).Utilising Computer-Assisted Qualitative Data Analysis Software. Retrieved from http:/atlastiblog.wordpress.com/2014/06/13/utilising-computer-assisted-qualitative-data- analysis-softwarein-buddhist-canonical-analysis.

Chiesser, G. (2015). What is at stake - Qu'est ce que l'enjeu? Paradoxes -Problematics. Sage publications

Creswell, J. W. (2013). Qualitative inquiry and research design: Choosing among five approaches (3rd ed.). Thousand Oaks, CA: Sage.

Creswell, J. W., \& Plano Clark, V. L. (2011). Designing and conducting mixed methods research (2nd ed.). Thousand Oaks, CA: Sage Publications, Inc.

Creswell, J. W. (2013). Research design: Qualitative, quantitative, and mixed methods approaches. Sage publications.

Croswell, J. W., (2013), Research design:Qualitative,quantitative and mixed methods approaches.Sage Publications

David, K., \& Solomon, M. G. (2012). Fundamentals of Information Systems Security. canada: Jones \& Bartlett learning .

Dianah, M. N. \& Joseph, M. M. (2012). Firm Efficiency Differences and Distribution in the Kenyan Manufacturing Sector. African Development Review, 24 (1), 52-66

Donald Bowersox, D. C., \& Cooper, M. B. (2012). Supply Chain Logistics Management $4^{\text {th }}$ Edition. Firth, R., 1951. Elements of Social Organization. Watts, London.

Elger (1962). Theory of Performance. Performance of supply chain systems; and mixed method approach theses. (4th ed.). Los Angeles: Sage.

Emery, N. \& Trist, K. (1960).Socio-technical Systems Theory of Acceptance. International Journal of Production Research, 49(8), 2285 - 2300.

Fuzile, L. (2015). Public Sector Supply Chain Management Review. Republic of South Africa: Department of National Treasury.

Gallegoa, J. M., Gutiérreza, L. H., \& Lee, S. H. (2011). A Firm-Level Analysis of ICT Adoption in an Emerging Economy:Evidence from the industries of columbia. Southeastern Louisian University USA: Department of Management and Business Administration.

Gamerschlag, R., Möller, K., \& Verbeeten, F. (2010). Determinants of voluntary CSR disclosure: empirical evidence from Germany. Review of Managerial Science, 1-30.

Gatari, N. C. (2014). Challenges Facing Implementation of Green Procurement In Manufacturing Sector in Kenya: A Case Study of Unga Limited Kenya , , . European Journal of Business Management, 2(1), 161173.

Gilaninia, S., Taleghani, M., Mousavian, S. J., Jalilvand, S., Khanjani, S., Rad, M. S., et al.(2012, january). Impact of Supply Chain dimensions on Customer Satisfaction. Kuwait

Githui M (2012). Responsible Purchasing and Supply Chain Management in Kenya: A Critical Analysis of the Ethical Considerations in Procurement Management. European Journal of Business and Management. Vol 4, No.3.

Glock, C. (2011) Lead time reduction strategies in single-vendor-single-buyer integrated inventory model with lot size-dependent lead times and stochastic demand. International journal of production economics. Vol 143Chapter of Arabian Journal of Business and Management Review, 1(5), 109-111.

Godinho, F. \& Veloso, S. (2012) From time based competition (TBC) to quick response (QRM): The evolution of research aimed at lead time reduction.International journal of advanced manufacturing technology. Vol 64, issue 5-8, p. 1177-91.

Greve, C. \& Davis, J. (2013). Recovering lost profits by improving reverse logistics. Pittsburg; Greve and Davis Publications.

Hausman, W. H. (2012). The practice of supply chain management: where theory and application converge. CA; Kluwer.

Flumian, M., (2018). Innovations in Public Services Delivery: Issue No. 6: The Management of Integrated Service Delivery: Lessons from Canada No. IDB-DP-00576). Inter-American Development Bank

Franzosi, Roberto; Doyle, Sophie; MeClelland, Laura; Putnam, Caddie \& Civari, Stefanie (2013).Quantitative Narrative Analysis Software Options Compared: PC-ACE \& CAQDAS(ATLAS.ti, MAXqda, and NVivo). Retrieved from

Friedman, K. (1956, 1957).Tendering Theory. The better understanding of supply chain management selection and practices. New York: Routledge.

Hwang, Y. (2011). Investigating the Influence of Cultural Orientation and Innovativeness on ERP Adoption. Journal of Global Information Technology Management, 14(3), 64-70.

Jader, J. (2012) Lead Time Reduction: Improving the Customer's Service Experience. 
Jeffreys, B. J., \& Thomas, O. (2010). challenges facing supply chain management in the oil marketing companies in Kenya. Nairobi: University of Nairobi.

Johnson, B. \& Christensen, L. (2012), Educational Research: Quantitative, Qualitative and Mixed Approach (4th ed.). California: SAGE $\backslash$ Publications Ltd.

Kamau, I. (2013). Buyer-Supplier relationships and organizational performance among large manufacturing firms in Nairobi-Kenya. Unpublished MBA thesis, University of Nairobi.

Kamau, S., (2016). Performance measurement practices and operational performance of manufacturing firms in Kenya. University of Nairobi Library Repository.

Kara, H (2012) Research and Evaluation for Busy Practitioners: A Time-Saving Guide, Bristol: The Policy Press.

Kariuki, E. N., \&Aduda, J., (2016). Procurement Performance Measurement in Commercial Banks in Kenya. International Journal of Business Strategies, 1(1), 10-25.

Karungani, W.P. \&Ochiri, G.(2017). Effect of internal procurement processes on organizational performance a case of Nairobi. International Journal of Economics, Commerce and Management United Kingdom, 5(7).

Katz. P. (1955). Skills Theory. The Three skilled knowledge education. California: SAGE Publications Ltd.

Kelly, B., (2014). The Influence of Corporate Reputation on Supplier Selection and Termination (Doctoral dissertation, Waterford Institute of Technology).

Kelly, S., \& MacDonald, P., (2016). A look at leadership styles and workplace solidarity communication. International Journal of Business Communication, 2329488416664176.

Kenya Association of Manufacturers (KAM). (2015). Kenya Manufacturers \& Exporters Directory, (11th ed.). Nairobi: Kenya Association of Manufacturers. Kenyan textile and fashion industry (2015) the role of fashion designers and small tailors in the fiber to fashion value chain. Retrieved from http://www.www.east-africa.hivos.org

Kerzner, H., \&Kerzner, H. R., (2017). Project management: a systems approach to planning, scheduling, and controlling. John Wiley \& Sons.

Kiage, J.O. (2013). Factors Affecting Procurement Performance: A Case of Ministry of Energy Published by Asian Society of Business and Commerce Research 54; International Journal of Business and Commerce Vol. 3, No.1: Sep 2013[54-70] (ISSN: 2225-2436)

Kilonzo, M. D., (2017). Procurement Ethics and Organizational Performance of Animal Feeds Manufacturing Firms In Kenya.

Klatt, F., (2015). Performance-based Specifications in Public Procurement: Exploring the Case of Germany (Bachelor's thesis, University of Twente).

KIPPRA. (2016). Kenya Economic Report. Nairobi: Kenya Institute For Public Policy Research and Analysis.

Kothari,C.R (2011). Research Methodology. Methods and Techniques. New Delhi: New Age International Publishers. (2nd Edition).

Kumar, T.M. (2015). E-Governance for Smart Cities. New York: Heidelberg Publishers

Lee, E., \& Wang, Y. (2011). An integrated resource management view of facilities management.

Washington DC: Pearson Education .

Livermore, R., \& Rippa, P. (2011). ERP Implementation: A Cross Cultural Perspective . Journal of Global Information Technology Management(14(3)), 25-26.

Lysons, K., \& Farrington, B. (2013). Purchasing and Supply Chain management. UK: pearson publishers.

Macharia, N. W.,Iravo, M.A.Ondabu, I.T. \& Ombu, K. (2015).Effects of Information Technology on Performance of Logistics Firms in Nairobi County. International Journal of Scientific and Research Publications, 5(4)

Mai, J. E., (2016). Looking for information: A survey of research on information seeking, needs, and behavior. Emerald Group Publishing.

Mailu, E., (2017). The Influence of strategic procurement practices on organizational performance of United Nations Agencies in Kenya-The Case of the United Nations Development Programme (Doctoral dissertation, Strathmore University).

Makali, J., \& Chirchir, M. M., (2015). Ethics and Procurement Performance of Humanitarian Organizations in Kenya (Doctoral dissertation, Doctoral Dissertation, University of Nairobi).

Mbaka, A.O. (2017). Influence of Integrated Financial Management Information System on Supply Chain Effectiveness: A Case of Kirinyaga County Government. Unpublished MSc Thesis, Nairobi: United States International University-Africa

Miles, M., Huberman, M. \& Saldaña, J. (2014). Qualitative data analysis: A methods source book. Thousand Oaks, CA: Sage Publications

Mogere, K., Oloko, M. \& Okibo, W. (2013).Effect of Inventory management practices on Operational Performance of Tea Processing Firms: A Case Study of Gianchore Tea Factory, Nyamira County, Kenya. The International Journal of Business \& Management, 1 (5), 12-27 
Monczka, R. M., Handfield, R. B., Giunipero, L. C., \& Patterson, J. L., (2015). Purchasing and supply chain management. Cengage Learning.

Muindi, J. M., (2017). The effectiveness of Strategic Human Resource Management Practices in Enhancing Performance: A Case of the Office of the Attorney-General and Department Of Justice in Kenya (Doctoral dissertation, United States International University-Africa).

Mullins, L.J. (2010),Management\& Organizational Behaviour, $9^{\text {Th }}$ Edition Financial Times Pitman Publishing.

Mundia, C., Langat, E.K., \& Lelegwe, S.(2015). Effect of Information System on Upstream Supply Chain Management among Supermarkets in Nakuru Town, Kenya. International Journal of Economics, Finance and Management Sciences. 3(5), 535-540.

Muthuri, J. N., \& Gilbert, V. (2011). An institutional analysis of corporate social responsibility In Kenya. Journal of Business Ethics, 98(3), 467-483.

Njeri, D. N., \& Were, S., (2017). Determinants Of Project Performance In Non-Governmental Organizations In Kenya, A Case Study Of Hand In Hand Eastern Africa. International Journal of Project Management, 1(4), 61-79.

Njogu, G. G., \& Gichinga, L., (2016). Factors Influencing Procurement Performance in State Corporations in Kenya-A Case Study of Kenya Ports Authority. International Journal of Innovative Research and Development, 5(6).

Normanyo, S. S., Ansah, J., \& Asante, D., (2016). The Public Procurement Market as a Platform for SME and National Economic Growth. European Journal of Logistics, Purchasing and Supply Chain Management, 4(4), 26-43.

Odero, J. \&Shitseswa, A.. (2017). Effect of procurement practices on procurement performance of public sugar manufacturing firms in western Kenya. International Journal of Management Research \& Review, 7(4): 521-535

Ogot, M. (2014). Evidence on Challenges Faced by Manufacturing Informal Sector Micro-Enterprises in Nairobi and Their Relationship with Strategic Choice. International Business Research. 7. 10.5539/ibr.v7n6p119.

Okundi, B. (2013). Procurement Laws Review Key to the Success of Devolution Retrieved from http://www.thestar.co.ke/news/article 132577/procurement-laws-review-keys devolution\#sthash.2bRg6zlv.dpuf..

Olubodun, N. E., (2015). The investigation into procurement risk management in the Nigeria oil and gas industry (Doctoral dissertation).

Oluoch, S.A. (2015). Effects of Technology Adoption on the Procurement Process at Kenya Maritime Authority Mombasa. The International Journal of Business \& Management 3(10)

Omisore, B. O., (2014). Strategies to improve the competence of public service officials in Nigeria. Journal of Public Administration and Governance, 3(4), 15-30.

Osei-Tutu, S., (2016). Compliance with Post Contract Procurement Procedures at Kumasi Meteropolitan Assembly (Doctoral dissertation).

Osoro, A., Muturi, W.M.,\&Ngugi, P.K.,(2015),Economic Data Analysis Affecting Performance of Supply Chain Systems in the Petroleum Industries in Kenya.The International Journal of Business \& Management,3(9),98.

Owuoth, G. G. \&Mwangangi, P.(2015). Effect of public procurement regulations on procurement performance in public sector in Kenya: a case of rural electrification authority. International Journal of Social Sciences Management and Entrepreneurship 2(1):171-184

Runeson, Goran \& Skitmore, Martin (1999) Tendering theory revisited. Construction Management and Economics, 17(3), 285-296.

Schmidt, A., (2017). Public Procurement Law and Reform in Developing Countries International Best Practices and Lessons Learned: Namibia as a Case Study. Nomos.

Shiferaw, B., (2015). Assessment Of The Existing Purchasing Policy And Practices And Its Effect On Performance: The Case of Ethiopian Airlines (Doctoral dissertation, St. Mary's University).

Simiyu, K. P. I., (2016). Factors Affecting Procurement of Goods In Government Ministries Case Of the National Treasury. Strategic Journal of Business \& Change Management, 3(2).

Solomon, P. N., \& Ayebale, D., (2017). Planning Competence and Staff Performance in Muni University, Uganda. European Journal of Management and Marketing Studies.

Sternberg, R.J., \&Lubart, T.I. (1991).An Investment Theory of Creativity and Development Journal of Human Resource Development, 34(1), 1-31.

Subba, G., (2016). Global and Local Context of Good Governance: A Study of Sikkim (Doctoral dissertation, Sikkim University).

Tabachnick, B. G., \&Fidell, L. S. (2013). Using Multivariate Statistics, $6^{\text {th }}$ ed. Boston: Allyn and Bacon.

Taylor, E. (n.d.).Differences in Supply Chain Designs for a Manufacturing Industry vs. a Service Industry Demand Media. Retrieved fromhttp://smallbusiness. chron.com/differences-upply chain-designsmanufacturing in industry- vs- service-industry- 14610 .htm 
Tobias, L. J., (2017). A Study of Teacher Job Satisfaction, Teacher Preferred Leadership Behaviors, and the Impact of the Leadership Behaviors on Teacher Job Satisfaction. Gardner-Webb University.

Topal, H. (2014) Whose Terms? A Glossary for Social Practice: RESEARCH ANALYSIS.Retrievedfrom http://www.newmuseum.org/blog/view/whose-terms-a-glossary-for- social- practice-research

Toroitich, J. K., Mburugu, K. N. \&Waweru, L. (2017). Influence of employee competence on the implementation of electronic procurement in the selected county governments in Kenya. International Academic Journal of Human Resource and Business Administration, 2(3), 242-254.

Von Clausewitz, C. (2014). Carl von Clausewitz: Historical and Political Writings. Princeton University Press.

Vyas-Doorgapersad, S \&Kinoti, A. (2015). Gender-based Public Procurement Practices in Kenya and South Africa. African Journal of Public Affairs, 8(3).

Wanyonyi, S. C., \& Muturi, W., (2015). Factors affecting the performance of procurement function among public technical training institutions in Kisumu County, Kenya. International Journal of Economics, Commerce, and Management, 3(5), 1-35

Watiri, L., \& Kihara, A. (2017). Influence of Supply Chain Management Practices on Competitive Advantage in Cement Manufacturing Industry: A Case of East African Portland Cement Company Limited. Strategic Journal of Business \& Change Management, 2(27), 461 - 481

Waweru, M, et al, (2015), A literature survey: Fuzzy logic and qualitative performance evaluation of supply chain management, the international journal of engineering and science, vol 4, pp56-63.

Weeks, M.P., \&Namusonge, G.S. (2016).Influence of Information Technology Practices in Procurement on Organization Performance in Public Institutions in Kenya. A Case of Jomo Kenyatta University of Agriculture and Technology. International Journal of Economics, Commerce and Management 4(5), pp 484-502. 